(C) А. В. Яцишин, В. А. Ткаченко, 2011 ISSN 2076-8184. Інформаційні технології і засоби навчання. 2011. №6 (26). Режим доступу до журналу: http://www.journal.iitta.gov.ua

УДК 02 : 004+37 : 001. 32] (477-25)

Яцишин Анна Володимирівна, кандидат педагогічних наук, старший науковий співробітник відділу комп’ютерно орієнтованих систем навчання та досліджень Інституту інформаційних технологій і засобів навчання НАПН України, м. Київ, еmail: svetlorusova@ukr.net.

Ткаченко Віталій Анатолійович, провідний інженер відділу комп'ютерно орієнтованих систем навчання та досліджень Інституту інформаційних технологій i засобів навчання НАПН України, м. Київ, е-mail: admin@iitta.gov.ua.

\title{
ЕЛЕКТРОННА БІБЛІОТЕКА НАЦІОНАЛЬНОЇ АКАДЕМЇ̈ ПЕДАГОГІЧНИХ НАУК УКРАЇНИ ЯК ОРГАНІЗАЦІЙНЕ НОВОВВЕДЕННЯ
}

\author{
Анотація \\ У статті визначено ключові поняття дослідження, охарактеризовано готовність
} організації і готовність наукових працівників до інноваційної діяльності, досліджено проблему готовності наукових працівників до впровадження наукової електронної бібліотеки Національної академії наук України (НАПН України), розглянуто види психологічних перешкод (бар'єрів) нововведенням, окреслено особливості взаємодії організації і нововведення та розроблено рекомендації для зменшення психологічного опору під час упровадження електронної бібліотеки НАПН України і можливих заходів для попередження соціальних і психологічних загроз.

Ключові слова: електронна бібліотека, НАПН України, нововведення, інновація, впровадження, психологічний опір, попередження психологічних загроз.

Оновлення всіх сфер соціального і духовного життя суспільства потребує якісно нового рівня від сучасної освіти і науки, які повинні відповідати міжнародним стандартам. В умовах сучасного інформаційного суспільства і щоденного оновлення і впровадження інформаційних технологій в усі сфери життя, важливим є питання, яке ставлять автори книги «E-Ukraine» [11], як домогтися того, щоб люди активно використовували сучасні технології після того, як отримають доступ до них? Це ще одне завдання освітнього характеру. Хтось вважає, що може залишатись осторонь всіх нововведень - адже все одно їх потік ніколи не припиняється, але тоді він мусить бути готовим до наслідків - відриву від решти суспільства і консервації у власному 
світі, що відмовився змінюватись [11]. Без бібліотечної справи неможливий розвиток освіти, культури, духовності і тому, важливими є інноваційні заходи у цій галузі.

На жаль, у бібліотечній справі нам залишається терпляче очікувати, коли державна бібліотечна політика отримає спрямування на підтримку і впровадження комплексних інновацій. Але яких інновацій ми прагнемо і до яких з них готові? Саме ступінь нашої готовності до конкретних системних змін і $є$ тією визначальною точкою відліку для їхнього початку [2].

Шевчук О. зазначає, що недостатньо надати в розпорядження людині нову техніку, навіть найрозумнішу і найзручнішу. Наскільки б вона не полегшувала життя i не розширювала коло можливостей індивіда, але доки кожна людина не прийме технологію як частину свого життя - значних зрушень у суспільстві не відбудеться [11]. Наступна проблема, яка виникає після технологічної розробки наукової електронної бібліотеки НАПН України, це - необхідність дослідження процесу соціально-психологічної адаптації наукових працівників до сприйняття інновацій, тобто процесу їі впровадження.

У науковій літературі зустрічаються праці, що стосуються розробки й упровадження наукової електронної бібліотеки (Іванова С. М. [3], Новицький О. В. [7], Прилуцька Н. С. [6], Резніченко В. А. [7], Спірін О. М. [7] та ін.), впливу інновацій на працівників освіти та інших галузей народного господарства (Краснокутська Н. В. [5], Чудакова В. [10], Іванкевич О. В. [2]), проте впровадження електронної бібліотеки НАПН України як організаційного нововведення і пов’язаних з цим проблем залишилося недослідженим і тому є актуальним.

Отже, метою статті є дослідження проблеми готовності наукових працівників до впровадження наукової електронної бібліотеки і розробка рекомендацій для зменшення психологічного опору під час упровадження електронної бібліотеки НАПН України і можливих заходів для попередження соціальних і психологічних загроз.

\section{Завдання дослідження}

1. Визначити ключові поняття дослідження й охарактеризувати готовність організації (готовність наукових працівників) до інноваційної діяльності.

2. Розглянути види психологічних перешкод (бар'єрів) нововведенням й окреслити особливості взаємодії організації і нововведення. 
3. Розробити рекомендації для зменшення психологічного опору під час упровадження електронної бібліотеки НАПН України і можливих заходів для попередження соціальних і психологічних загроз.

Впровадження й адаптація будь-яких нововведень завжди було важким i неоднозначний процесом. Важливим є розв’язання проблеми відношення людей до організаційних нововведень, а також діагностування їхньої поведінки в умовах впровадження електронної бібліотеки в установах НАПН України. Означена наукова електронна бібліотека НАПН України (http://lib.iitta.gov.ua) була розроблена й упроваджується за результатами НДР «Науково-організаційні засади забезпечення функціонування єдиного інформаційного простору бібліотек наукових і навчальних закладів АПН України», яка виконувалась в Інституті інформаційних технологій i засобів навчання НАПН України у 2009-2011рр.

Окреслимо ключові поняття, такі як «нововведення», «новація», «інновація», «інноваційний процес», для правильного вживання їх у контексті дослідження.

Нововведення - 1) комплексний процес створення, розповсюдження та використання нового практичного засобу (новацій); 2) форма організації інноваційної діяльності; 3) є першим застосуванням нового продукту або процесу; 4) комплексний, цілеспрямований процес створення, розповсюдження та використання нового, метою якого є задоволення потреб й інтересів людей новими засобами, що веде до певних якісних змін системи i способів забезпечення ефективності, стабільності та життєздатності [8]; 5) процес, у ході якого винахід або відкриття доводиться до стадії практичного застосування і починає давати економічний ефект [4].

Інновації - 1) об’ єкти впровадження чи процес, що веде до появи чогось нового - новації; 2) ідеї і пропозиції (у багатьох випадках засновані на результатах відповідних спеціальних наукових досліджень й інженерних розробок), що можуть стати основою створення нових видів продукції чи значно поліпшити споживчі характеристики (технічні, економічні тощо) існуючих товарів, створення нових процесів, послуг, чи будь-чого, що може покращити «якість життя» людства [4]; 3) вперше створені, удосконалені або застосовувані освітні, дидактичні, виховні, управлінські системи, їхні компоненти, що суттєво поліпшують результати освітньої діяльності [8]. Інновації в освіті - процес створення, запровадження та поширення в освітній практиці ідей, засобів, педагогічних і управлінських технологій, у результаті 
яких підвищуються показники досягнень структурних компонентів освіти, відбувається перехід системи до якісно нового стану. Слово «інновація» має комплексне значення, оскільки складається 3 двох форм: власне ідеї і процесу іiі практичної реалізації [1, с. 338]. Будь-яке соціально-економічне нововведення, доки воно не отримало масового, тобто серійного поширення в галузі праці, виробництва й управління можна вважати інновацією [4].

Життєвим циклом інновації називають період від зародження ідеї, створення, поширення нововведення i до його впровадження. 3 урахуванням послідовності проведення робіт життєвий цикл інновації розглядається як інноваційний процес, цей процес має свого генератора (творця, автора) і суб'єктів впливу, які, ймовірно, чинитимуть опір або можуть бути споживачами інновації [2].

Інноваційний процес - це сукупність науково-технічних, технологічних i організаційних змін, що відбуваються у процесі реалізації інновацій [4]. Його перебіг визначається складною взаємодією різних чинників, а повну ефективність інноваційного процесу можна визначити лише після впровадження інновації. Інноваційний процес не завершується тільки впровадженням новації (електронна бібліотека НАПН України), бо має неперервний характер, адже 3 поширенням інновація вдосконалюється, і стає більш ефективною, набуває нових якостей, нові можливості застосування, і нових споживачів. Тобто, інноваційний процес можна визначити як засіб задоволення суспільних потреб на основі впровадження досягнень науки i технології, які повинні полегшити людську працю i зробити іiі продуктивнішою.

Ми погоджуємося з Іванкевичем О. В., який підкреслює, що в основі любої інновації завжди знаходиться інноваційна ідея, що є новим знанням 3 метою його практичного застосування i, безперечно, передбачає матеріалізацію нових ідей і знань 3 метою задоволення інформаційних потреб користувачів. Неодмінними властивостями впровадження нових і цікавих форм роботи, використання інновації $€$ наукова (бібліотекознавча), технічна (з використанням сучасних інформаційних технологій) новизна і виробнича доцільність [2].

Актуальним $є$ необхідність вивчення інноваційного розвитку суспільства i закономірностей з цим пов’язаних, саме тепер, коли людство вступило у новий етап 
свого розвитку - інформаційне суспільство, підгрунттям життєдіяльності якого є процеси пов’ язані з виробництвом, розповсюдженням і використанням інформації.

Як зазначає Чудакова В. [10], «... теперішній етап розвитку освіти в умовах несприятливого впливу економічних $\mathrm{i}$ соціально-культурних чинників характеризується пошуком шляхів, способів i засобів самовдосконалення, саморозвитку, самоактуалізації творчої конкурентоздатної особистості...», спроможної «фільтрувати» відомості, здобуті 3 різних джерел й активно використовувати сучасні наукові здобутки і технічні засоби.

Унаслідок нововведень, зазвичай, зазнають змін такі головні елементи організації:

- організаційні структури i системи (інформаційні системи, механізми моніторингу і контролю, посадові інструкції, формальні системи оплати i винагороди, структури нарад, виробнича політика тощо);

- організаційна культура (цінності, ритуали, джерела влади, лояльність, норми, неформальне заохочення, санкції тощо);

- співробітники (різноманітні навички, знання та досвід, особистісні якості, цінності, відносини та поведінка) [5].

Іванкевич О. В. зауважує, що важливе значення має оцінка можливого ефекту від реалізації нововведення. Ефект може бути економічним, фінансовим, соціальним, ресурсним, технологічним або проявлятися в нематеріальній сфері (новизна, корисність, надійність тощо) [2].

Важливе значення для пояснення поведінки людини в постійно змінному світі мають положення первинної, превентивної активності особистості відносно навколишнього середовища й ініційованих нею змін. Поведінка і діяльність суб' єктів визначається сприйняттям певних подій і явищ, це і означає, що ставлення людини до різних змін активним чином впливає на сприйняття нововведень, ставлення до них $\mathrm{i}$ участь в їх реалізації.

Інновації в освітній галузі відображають складний і довготривалий процес, провідне місце відводиться науковим співробітникам, яким треба сприйняти i реалізувати нововведення [10]. І саме від їх готовності до інноваційної діяльності, від їх ставлення до цього нововведення залежать успіх і ефективність впровадження електронної бібліотеки НАПН України. 
На думку авторів, необхідно також приділити увагу дослідженню проблеми 3 формування готовності наукових працівників до інноваційної діяльності, розробці рекомендацій для зменшення психологічного опору під час упровадження електронної бібліотеки НАПН України і можливих заходів для попередження соціальних і психологічних загроз.

Якщо керівник організації буде знати групи людей, котрі різняться за своїм ставленням до змін, то, можливо, чітко визначити готовність працівників (i організації в цілому) до впровадження нововведення. Загальновідомо, що чим менша сила опору нововведенню, тим краща ситуація, і навпаки.

Усвідомлення в необхідності нововведення відбувається не одразу і не всіма працівниками організації. За Краснокутською Н. В. «... процес визрівання» людини (чи групи) до готовності сприймати нову ідею відбувається послідовно і може охоплювати кілька етапів: 1) поява людей, які «переживають» проблему, тобто відчувають наближення змін, що вимагають дій у відповідь; 2) виникнення ідеї перетворення; 3) оформлення проекту перетворення (зосередження уваги на елементі організації, який потребує перетворення, опис його реального стану та очікуваного в майбутньому; 4) виникнення групи прихильників проекту, яка визначить реальну можливість його здійснення; 5) прийняття рішення про здійснення змін, яке підкріплюється програмою нововведення і визначенням конкретних учасників [5].

Часто в організації можуть виникнути психологічні перешкоди (бар'єри) нововведенням - мотиваційні чинники, які ускладнюють пов'язану з нововведеннями діяльність. Керівнику бажано бути ознайомленим і підготовленим до подолання цих психологічних перешкод, щоб краще відчувати ситуацію й ефективніше використовувати засоби і методи їх подолання. Зазвичай людина не може без нового, але в кожного своя межа сприймання змін (терпимості до них). Люди з низькою межею терпимості до змін вигадують безліч причин, намагаючись переконати в їх недоцільності або неможливості. Також, у багатьох людей зміни можуть викликати навіть стресові реакції тому, важливим є психологічна підготовка людей до змін [5].

У навчальному посібнику з інноваційного менеджменту роз'яснюється, що психологічні бар'єри на шляху до перетворень пов'язані не тільки зі змінами обставин життя людей, а й 3 непередбачуваністю або зміною майбутнього: прогнозоване розширення можливостей зумовлює позитивне ставлення до інновацій, 
а прогнозоване звуження можливостей - опір їм. Породжувати психологічні бар'єри можуть як суб' єктивні, так і об'єктивні чинники [5].

Під час впровадження наукової електронної бібліотеки НАПН України можуть проявлятися такі види психологічних бар'єрів:

1. Бар'єр некомпетентності, може виникнути в невпевнених у своїх силах співробітників, які побоюються, що після змін не зможуть як слід виконувати свої обов'язки. Пов’язаний із сумнівами у здатності підвищити свою кваліфікацію або перекваліфікуватися. Його можна подолати за попереднього обговорення i ознайомлення 3 нововведенням працівників організації.

2. Бар'єр навичок, звичок, традищій, його породжують намагання людини зберегти існуючий спосіб роботи. Цей бар'єр подолати складно і для початку варто передбачити, як за нових умов використати сформовані навички, звички, традиції. У процесі впровадження нововведення це послабить дискомфортні переживання, які спричинені інноваційними процесами.

3. Бар'єр ідилї, він спричинений задоволенням працівників усіма умовами, які надала організація (статусом, матеріальним забезпеченням тощо). Інколи працівники задоволені надто малим, оскільки не знають, що можна працювати і жити краще. Щоб подолати цей бар'єр потрібно порівняти реальний стан справ із тим, що може бути досягнутий внаслідок впровадження конкретного нововведення, пояснити, що це нововведення дійсно корисне і поліпшує ефективність праці співробітників.

4. Бар'єр збільшення навантаження, як правило, новації, передбачають розширення виконуваної роботи, але це виникає тільки на початку. Ці зміни працівники сприймають як збільшення навантаження, що й зумовлює негативне ставлення до них, нейтралізувати його можуть переконаність у тому, що нововведення в подальшому забезпечить підвищення конкурентноздатності наукової продукції співробітника, як наслідок підвищення авторитету організації, вихід на міжнародний освітній простір і підвищення авторитету самого співробітника.

5. Бар'єр компенсації, властивий насамперед тим, хто намагається будь-що уникнути незручностей. Він проявляється через переживання, пов'язані 3 невпевненістю, що додаткові зусилля будуть відповідно компенсовані. Цей бар'єр не є неподоланним для змін, керівництву бажано, враховувати індивідуальні якості своїх співробітників і чітко використовувати моральне і матеріальне стимулювання. 
6. Бар’єр «сочіальний затишок», працюючи певний час у колективі, люди набувають відповідного статусу, який 3 роками підвищується, що впливає на задоволеність своїм становищем. Під час впровадження нововведення працівники остерігаються, що цей статус може похитнутися, зруйнуються раніше сформовані відносини, адже інші працівники можуть змінити своє ставлення, що пов'язане із швидким опануванням новації чи навпаки, оскільки наприклад, цю людину раніше поважали за новаторство й ініціативність, а тепер ця особа не може швидко опанувати нововведення [5].

Саме науковці і є носіями сучасних педагогічних інновацій, які їх створюють i впроваджують, і повинні бути здатними до професійного самовдосконалення, яке здійснюється у двох взаємопов’ язаних формах:

- самовиховання - цілеспрямована діяльність людини щодо систематичного формування i розвитку в собі позитивних й усунення негативних якостей особистості, відповідно до усвідомлених потреб відповідно соціальним вимогам;

- самоосвіта - оновлення й удосконалення наявних у спеціаліста знань, умінь i навичок з метою досягнення бажаного рівня професійної компетентності [10]. Час освоєння нововведення певною організацією порівняно 3 іншими ще називають сприйнятливістю організації до нововведень. Опанування нововведення складається 3 двох стадій: 1) ініціювання - процес, за допомогою якого організація дізнається про новацію й вирішує її опанувати; 2) впровадженням називають процес, за допомогою якого організація здійснює інновацію і вона стає невід’ємною частиною самої організації. Сприйнятливість організації до нововведень розглядається як похідна кількох груп чинників структурних, індивідуально-психологічних, ринкових, комунікаційних, контекстуальних. Тобто, чим раніше прийнято рішення про впровадження інновацій або чим більше буде освоєно нововведень за деякий період порівняно 3 іншими суб'єктами опанування нововведень, тим i $\epsilon$ вища сприйнятливість організації до нововведення [5, с. 236-237].

Для ефективного управління процесом впровадження електронної бібліотеки в установах НАПН України керівникам бажано спочатку переконати наукових працівників у перевагах електронної бібліотеки, заохотити до іiї наповнення науковими публікаціями та іншими матеріалами, до яких відносяться електронних 
презентацій, записи відео- і аудіовиступів на конференціях, семінарах, на телебаченні та ін. Оскільки для їх розробки наукові працівники теж витрачають багато часу, і ці матеріали $\epsilon$ «інтелектуальною продукцією» i можуть бути використані як для навчальних, виховних цілей і для наукових досліджень.

Загальновідомо, що успіх інновацій визначається здібністю людей до інноваційної, творчої, пошукової діяльності, особливе значення має рівень розвитку такого виду мотивації, як мотивація самовдосконалення особистості (сукупність спонукань i внутрішніх умов, мотиваційних характеристик, які визначають, направляють i регулюють процес підвищення професійної компетентності особистісного зростання) [10].

Між нововведенням й організацією завжди існує зв'язок, особливість якого впливає на процес впровадження і поширення нововведення. У книжці «Управління змінами» [9, с. 239-240] визначено п’ять типів таких відносин: організація як користувач інноваціями; організація як створювач інновацій; організація як користувач і одночасно створювач нововведень; організація як носій нововведень; організація як нововведення. За Краснокутською Н. В., вивчення різних типів взаємозв'язків між нововведенням й організацією надасть змогу розглянути феномен нововведення, як явище, що впливає на діяльність організації і його результати, і як процес, розвиток якого залежить від організації, системи управління, ставлення працівників до інновацій [5, с. 228-229].

Для врахування впливу особливостей організацій на впровадження і поширення інновацій важливим є дослідження взаємодії нововведень і організацій у нових умовах. За визначенням Джона Р. Кімберлі [9, с. 239-240], вивчення особливостей взаємодії нововведення й організації $\epsilon$ особливо важливе для подальшого розвитку саме організації. Отже, розглянемо ці особливості детальніше:

1) організація як користувач інновації - даний тип взаємодії грунтується на критерії, що нововведення - благо, і чим більше нововведень, тим краще. Головна проблема в тому, як підсилити сприйнятливість організації до нововведень i прискорити процес поширення й опанування інновацій серед потенційних користувачів. Якщо нововведення у сфері освіти, і коли організація є користувачем нововведення, то на кінцевий результат впливають, як властивості самої організації, 
так і властивості нововведення. I тому, їх варто розглядати у взаємозв'язку: організації обирають ті нововведення, які, на їхню думку, мають перспективу;

2) організація як творець нововведення - організації, самі ініціатори і розробники новацій. Важливим завданням стає пошук шляхів збільшення обсягів нововведень і скорочення часу виходу їх на ринок послуг. Керівництво організації змушене зосередитись на організаційних аспектах управління нововведеннями, стимулюванні активності працівників, підвищенні активності вивчення попиту i потреб споживачів (користувачів). У цій ситуації важливим $є$ всебічний розвиток інноваційного потенціалу організації, активності і продуктивності науково-дослідних підрозділів, що виконують фундаментальні i науково-прикладні дослідження i розробки, тобто, особлива увага приділяється тому, щоб під час апробації новації, i можливих рекомендацій щодо іiі вдосконалення постійно передавались у підрозділ, який і здійснює цю НДР. Усе це і створює потрібний інноваційний клімат, який забезпечить певний «прорив» в інноваційній діяльності організації, адже відповідно забезпечує оновлення новації, іiї якості, створення нових властивостей, які задовольняють нові потреби;

3) організація як розробник і користувач нововведення, цей тип взаємозв'язку між організацією і нововведенням називають ще «внутрішнім нововведенням», ці організації своїми розробками значно впливають на науково-технічну політику відповідних галузей. 3 назви зрозуміло, що організація самостійно розробляє нововведення. Наприклад, Інститут інформаційних технологій і засобів навчання НАПН України розробив електронну бібліотеку НАПН України (http://ib.iitta.gov.ua), з метою задоволення академічних потреб. Перш за все, важливим завдання тут постає потреба в необхідності силами організації швидше розв’язувати проблеми в реальному масштабі часу, ніж створювати новацію для зовнішніх користувачів за допомогою інших наукових центрів. I надалі, на основі цієї наукової електронної бібліотеки можливо створювати мережу академічних бібліотек. У цій ситуації, проблема полягає у створенні потенціалу самовідновлення організації, внутрішнього соціально-психологічного клімату, який сприятиме поширенню новації, внутрішній гармонії, синхронності в удосконаленні новації, і потребує координації роботи всіх підрозділів даної організації; 
4) організація як носій нововведення, інколи для впровадження певних нововведень у практику потрібні нові організаційні форми, без яких нововведення залишається недоступними потенційним споживачам. Такий тип взаємозв' язків між нововведенням й організацією полягає в тому, що організаційні форми як носії нововведення самі $є$ новими. Поява нової організаційної форми сприяє породженню в навколишньому середовищі нестабільності, ніхто не знає, що очікувати від нової організації і як до неї ставитися. Завдання керівництва полягає у забезпеченні суспільного визнання нової організації, а це означає потрібно зробити все необхідне, щоб усі розуміли, чим є нова форма організації і що вона робить та які має результати в інноваційній діяльності;

5) організація як нововведення, організація сама стає нововведенням. До них відносяться різноманітні організаційні форми взаємодії науки - виробництва використання: науково-технічні центри, державні організації, що призначені для зміцнення зв'язків між промисловими фірмами й університетами, для консолідації фондів, що забезпечують розвиток дослідних робіт i появу нових технічних досягнень, технопарки, технополіси [5, с. 230-232].

Звичайно, що будь-які новації потребують витрат ресурсів (праці, часу, фінансів тощо), а сам процес упровадження нововведення потребує витрат, головною 3 яких є час [2].

В організації розрізняють два типи нововведень: 1) організаційні, які $є$ результатом організаційних рішень і не потребують зміни індивідуальної поведінки від більшості членів організації, наприклад, освоєння нової продукції, змінюється організація, як ціле, а не поведінка більшості ii робітників; 2) нововведення в організації, які потребують зміни поведінки індивідів, реорганізація організаційної структури, перебудова структури комунікацій, зміна вимог до персоналу, зміни технологій і організації виробництва, і потребують нової кваліфікації робітників, ціннісних орієнтацій, відмови від стереотипів поведінки [5, с. 236-237].

Упровадження нововведення пов'язане 3 різноманітними психологічними чинниками і залежить від людей, які є ініціаторами, тими, хто підтримує і хто їм активно протистоїть. Вплив нововведення на наукових працівників, також, залежить від того, наскільки переконливо представлено актуальність i необхідність впровадження електронної бібліотеки НАПН України як нововведення. 
Під час впровадження будь-якого обгрунтованого нововведення неминуче відбувається поділ працівників на кілька груп з різною реакцією на інновацію, це можуть бути активні противники, скептики, байдужі, прихильники та ентузіасти.

Розглянемо окремі групові утворення:

1) активні противники - негативно ставляться до нововведень, іноді чинять опір нововведенню і намагаються залучити до цього і тих, хто ще визначився не повністю;

2) скептики або вербальні противники, які на словах виявляють незадоволення нововведеннями, однак за власною ініціативою не вдаються до жодних практичних кроків, які б унеможливили зміни;

3) байдужі - ставиться до будь-яких змін і нововведень байдуже, бо вважають, що нововведення зовсім не впливає на їхню трудову діяльність;

4) прихильники, зазвичай, схвалюють і на словах підтримують нововведення, однак у користуванні інновацією проявляють мало ініціативи. Також, іноді у них виникають сумніви щодо ефективності й актуальності нововведення;

5) ентузіасти - активні прихильники змін, вони підтримують їх і на словах, і на практиці й намагаються залучити до нової справи якомога більше людей в організації $[5]$.

За Краснокутською Н. В. розглянемо способи подолання опору 3 використанням низки підходів.

1. Інформування про нововведення до того, як воно буде впроваджене. Що надасть можливість співробітникам 3'ясувати важливі питання, висловити побоювання з приводу передбачуваної новації.

2. Залучення наукових працівників до обговорення нововведення. Оскільки це є свідченням готовності ініціаторів новації вислухати осіб, яких вона торкнеться, використати їхні поради. Відкрите спілкування і взаємодія допоможуть усвідомити важливість змін, зрозуміти, що в процесі прийняття рішення враховувалась і думка колективу.

3. Підтримка і допомога. Залежать від типу перетворень і можуть охоплювати навчання нових навичок, управління стресом, обговорення спільних проблем, конкретну підтримку співробітників, котрі потребують допомоги в освоєнні новації. 
4. Угоди і переговори. Цю тактику з групами співробітників, використовують, коли нововведення реально ставить певних осіб у програшне становище [5].

Будь-які нововведення несуть у собі непередбачуваність і певний ризик, можуть викликати, навіть, стресову реакцію у працівників, які обирають різні індивідуальні стратегії поведінки в проблемних ситуаціях: одні надають перевагу активним діям і подоланню проблем, а інші вичікують, доки проблема розв'яжеться сама.

Інститут інформаційних технологій i засобів навчання НАПН України забезпечить:

- постійний науковий супровід на етапах розробки, апробації, впровадження, наповнення, а також проведення роз'яснювальної роботи;

- $\quad$ проведення практичних семінарів, круглих столів, тренінгів у тому місці, і у той час, коли зручно для працівників установ НАПН України;

- $\quad$ співпрацю науковців, які розробили електронну бібліотеку, з тими хто їі наповнює. Що допоможе своєчасно проводити корективи, доповнення і знаходити оптимальне розв’ язання проблем, що виникають у процесі впровадження електронної бібліотеки НАПН України.

Проведене дослідження дало можливість визначити такі результати: визначено ключові поняття дослідження; охарактеризовано готовність організації і готовність наукових працівників до інноваційної діяльності; описано види психологічних перешкод (бар'єрів) нововведенням й окреслено особливості взаємодії організації і нововведення; розроблено можливі заходи i рекомендації для зменшення психологічного опору під час упровадження електронної бібліотеки НАПН України.

Викладене вище дає можливість зробити такі висновки:

1) інновації в освітній галузі є складним і довготривалим процесом, у якому провідне місце відводиться науковим співробітникам, яким треба сприйняти й упроваджувати «опановувати» нововведення. І саме від їх готовності до інноваційної діяльності, від їх ставлення до цього нововведення залежать успіх і ефективність впровадження електронної бібліотеки НАПН України;

2) у процесі впровадження наукової електронної бібліотеки НАПН України можуть проявлятися такі види психологічних бар'єрів: «некомпетентності», «навичок, звичок, традицій», «ідилії», «збільшення навантаження», «компенсації», 
«соціальний затишок». Окреслено п’ять типів взаємодії організації і нововведень: організація як користувач інноваціями; організація як створювач інновацій; організація як розробник i користувач нововведення; організація як носій нововведень; організація як нововведення;

3) ефективним $є$ проведення низки заходів щодо впровадження електронної бібліотеки НАПН України на базі різних установ структури НАПН України: практичних семінарів, круглих столів, тренінгів. Це дасть змогу заощадити державні кошти (кошти наукових установ), які необхідно витратити для відрядження великої кількості учасників семінарів (кошти необхідні тільки для відряджень тих, хто буде представляти і роз'яснювати правила користування електронною бібліотекою, а це 34 особи). Що дасть змогу регулювати процес розвитку й упровадження електронної бібліотеки НАПН України як організаційного нововведення і посилити іiі практичну значимість.

Проведене дослідження не вичерпує всіх аспектів окресленої проблеми в подальшому актуальними залишаються питання пов'язані 3 процесом соціальнопсихологічної адаптації наукових працівників до впровадження наукової електронної бібліотеки НАПН України тощо.

\section{Список використаних джерел}

1. Енциклопедія освіти / [Акад. пед. наук України; гол. ред. В. Г. Кремень]. - К. : Юрінком Інтер, 2008. - 1040 с.

2. Іванкевич O. В. Роль бібліотеки в процесах впровадження інновацій [Електронний ресурс] / Іванкевич О. В. - 2011. - Режим доступу : http://www.lib.nau.edu.ua/forum/default.aspx?g=posts\&t=52.

3. І Іванова С. M. Тенденції використання електронних бібліотек в наукових $\mathrm{i}$ навчальних закладах (зарубіжний і вітчизняний досвід) [Електронний ресурс] / C. М. Іванова // Інформаційні технології і засоби навчання. - 2011. - №3 (23). - Режим доступу до журналу : http://journal.iitta.gov.ua/index.php/itlt/issue/view/42.

4. Інновації [Електронний ресурс] / Вікіпедія. Вільна енциклопедія. - 2011. - Режим доступу : http://uk.wikipedia.org/wiki.

5. Краснокутська H. B. Інноваційний менеджмент : навч. посіб. / Н. В. Краснокутська - К. : КНЕУ, 2003. - 504 с. 
6. Прилуц̧ька Н. C. Особливості функціонування наукових і освітніх електронних бібліотек [Електронний ресурс] / Н. С. Прилуцька. // Інформаційні технології і засоби навчання. - 2011. - №2 (22). - Режим доступу до журналу : http://www.journal.iitta.gov.ua.

7. Спірін О. М. Проектування системи електронних бібліотек наукових і навчальних закладів АПН України [Електронний ресурс] / О. М. Спірін, В. М. Саух, В. А. Резніченко, О. В. Новицький // Інформаційні технології і засоби навчання. 2009. - №6 (14). - Режим доступу до журналу : http://www.ime.edu-ua.net/em.html.

\begin{tabular}{l} 
8. Тлумачення поняття інновація у науковій літературі [Електронний \\
\hline
\end{tabular} pecypc] / Веб-сайт ЦПТО 1. - 2011. - Режим доступу : http://www.cpto1.vn.ua/page.php.

9. Управление изменениями : хрестоматия / под ред. Широковой Г. В. : пер. с англ. ; С.-петерб. гос. ун-т. Высш. шк. менеджмента. - 2-е изд. - СПб. : Изд-во Высш. шк. менеджмента, 2010. - 520 с.

10. Чудакова B. Психологічний супровід інноваційних освітніх проектів : мотиваційний компонент [Електронний ресурс] / В. Чудакова. - 2011. - Режим доступу : http://osvita.ua/school/psychology/1281.

11. Шевчук O. E-Ukraine. (Електронна Україна) [Електронний ресурс] / Шевчук О., Голобуцький О. - 2011. - Режим доступу : $\quad$ http://www.eukraine.biz/index.html.

\section{ЭЛЕКТРОННАЯ БИБЛИОТЕКА НАЦИОНАЛЬНОЙ АКАДЕМИИ ПЕДАГОГИЧЕСКИХ НАУК УКРАИНЫ КАК ОРГАНИЗАЦИОННОЕ НОВОВВЕДЕНИЕ}

Яцишин Анна Владимировна, кандидат педагогических наук, старший научный сотрудник отдела компьютерно ориентированных систем обучения и исследований Института информационных технологий и средств обучения НАПН Украины, г. Киев, e-mail: svetlorusova@ukr.net.

Ткаченко Виталий Анатольевич, ведущий инженер отдела компьютерно ориентированных систем обучения и исследований Института информационных технологий и средств обучения НАПН Украины, г. Киев, e-mail: admin @iitta.gov.ua.

\section{Аннотация}

В статье определены ключевые понятия исследования, охарактеризованы готовность организации и готовность научных работников к инновационной 
деятельности, исследована проблема готовности научных работников к внедрению научной электронной библиотеки Национальной академии наук Украины (НАПН Украины), рассмотрены виды психологических препятствий (барьеров) нововведением, очерчены особенности взаимодействия организации и нововведения, и разработаны рекомендации для уменьшения психологического сопротивления при внедрении электронной библиотеки НАПН Украины и возможные меры для предупреждения социальных и психологических угроз.

Ключевые слова: электронная библиотека, НАПН Украины, нововведение, инновация, внедрение, психологическое сопротивление, предупреждение психологических угроз.

\section{E-LIBRARY OF THE NATIONAL ACADEMY OF PEDAGOGICAL SCIENCES OF UKRAINE AS AN ORGANIZATIONAL INNOVATION}

Anna V. Yatsishin, PhD (pedagogical sciences), senior researcher of Computer-Oriented Systems' Department, Institute of Information Technologies and Learning Tools of NAPS of Ukraine, Kyiv, e-mail:svetlorusova@ukr.net.

Vitaliy A. Tkachenko, senior engineer of Computer-Oriented Systems' Department, Institute of Information Technologies and Learning Tools of NAPS of Ukraine, Kyiv,email: admin@iitta.gov.ua.

\section{Resume}

The article identifies the key concepts of the study, describes organizational willingness and readiness of researchers for innovations, investigates the problem of researchers' readiness for implementation of the e-library of the National Academy of Pedagogical Sciences of Ukraine (NAPS of Ukraine), examines the psychological barriers for innovation, outlines the features of the organization and innovation interaction, develops the recommendations for reducing the psychological resistance to the introduction of an electronic library of NAPS Ukraine and possible measures to prevent social and psychological threats.

Key words: e-library, NAPS of Ukraine, innovation, implementation, psychological resistance, psychological threats' prevention.

Матеріал надійшов до редакції 13.12.2011 р. 